UDC 582-152.42 (477.85)

\title{
CHOROLOGICAL, ECOLOGICAL AND COENOTIC CHARACTERISTICS OF SYMPHYOTRICHUM CILIATUM (LINDL.) NESOM (ASTERACEAE) IN THE BUKOVINIAN CIS-CARPATHIAN
}

\author{
A. I. Tokaryuk', I. I. Chorney', V. V. Budzhak', V. V. Protopopova', M. V. Shevera ${ }^{3,2}$ \\ ${ }^{1}$ Yuryi Fedkovych Chernivtsi National University, 11, Fedkovych St., Chernivtsi 58022, Ukraine \\ e-mail: iichorney@ukr.net, vbudzhak@gmail.com \\ ${ }^{2}$ Ferenc Rakoczi II Transcarpathian Hungarian Institute \\ 6, Koshut Sq., Beregovo 90200, Ukraine \\ e-mail: protopopova.vira@gmail.com \\ ${ }^{3}$ M.G. Kholodny Institute of Botany, NAS of Ukraine \\ 2, Tereschenkivska St., Kyiv 01004, Ukraine \\ e-mail: shevera.myroslav@gmail.com
}

The results of study on distribution, ecological and coenotic characteristics of alien species Symphyotrichum ciliatum (Lindl.) Nesom (Asteraceae) in the Bukovinian CisCarpathian (Chernivtsi Region, Ukraine) are presented. Five associations of synanthropic vegetation species were found in the region namely: Eragrostio-Amaranthetum albi Morariu 1943, class Digitario sanguinalis-Eragrostietea minoris Mucina, Lososová et Šilc in Mucina et al. 2016, Lolio-Plantaginetum majoris (Linkola 1921) Beger and Polygonetum arenastri Gams 1927, class Polygono-Poetea annuae Rivas-Mart. 1975, Odontito-Ambrosietum artemisiifoliae Mucina 1993 and Convolvulo-Agropyretum repentis Felföldy 1943, class Artemisietea vulgaris Lohmeyer et al. in Tx. ex von Rochow 1951. These species are noted in the anthropogenic ecotopes and in habitat of Nature 2000. The indices of main edaphic and climatic factors for the species were determined for the first time. According to the main climatic indices, such as thermoregulation, ombrorezhime and criorezhime, S. ciliatum is characterized by stenotopic amplitude and belongs to submezoterms, subaridophytes and hemicriophytes, etc. S. ciliatum in the region is characterized as potential invasive species.

Keywords: Symphyotrichum ciliatum, Asteraceae, distribution, ecological and coenotic characteristics, the Bukovinian Cis-Carpathian, Ukraine

\section{INTRODUCTION}

Symphyotrichum ciliatum (Lindl.) Nesom (Brachyactis ciliata (Ledeb.) Ledeb.) is an alien species with the debatable systematic position caused its high variability, vague diagnostic morphological features, disjunctive area etc. Previously florists and taxonomists have considered this species as a member of different genera, e.g. Aster L., 
Erigeron L., Conyza Less., Tripolium Nees. In Europe it was often referred to the genus Brachyactis Ledeb. [12, 26, 32] or to the genus Symphyotrichum Nees [2, 17, 23, 31]. Due to the karyological studies carried out by Nesom [17] it was established that species of genera Symphyotrichum and Brachyactis had the different number of chromosomes, $(2 n=14)$ and $(2 n=18)$ respectively. This and also significant distinction between taxa have been allowed consider the studied species as a member of the section Conyzopsis (Torr \& A. Gray) G.L. Nesom, subgenus Symphyotrichum, genus Symphyotrichum [2, 17, 23, 31].

An interpretation of the origin of this species is also debatable: as $S$. ciliatum, sub nom. B. ciliate it maybe Asian [1, 9-10, 12, 24-26, 32] or North American [13]; as S. ciliatum it maybe North American, North and Middle Asian [30]. However study conducted by G.L. Nesom [17] showed that European populations as well as North American ones have the number of chromosomes $2 n=14$ and therefore it is necessarily to include them in the genus Symphyotrichum.

The natural area of S. ciliatum is North America (Rocky Mountains) where it grows in dry places. Later the species migrated to the prairie of the Great Plains, and also through Alaska and the Bering Strait to the North-Eastern of Asia.

The general area of $S$. ciliatum is Circumpolar, disjunctive. It distributes in North America, West and East Sibirian, Fare East and Central Asia [2, 12, 17, 26]. At present its active distribution is observed in the East of the American continent [4] and in Europe (Ukraine, Moldova, Romania, Poland, Slovakia, Russia) [7-10, 18, 24, 31], where S. ciliatum manifests a wide ecological amplitude growing on different substrata from dry sands to saline, moist soils, but mostly prefers some anthropogenic habitats.

In Ukraine, S. ciliatum (sub nom. B. ciliate) was first recorded in Danube Biosphere Reserve [7]. Later it has been found in Steppe, mainly in the anthropogenic and seminatural (coastal, seaside and steppe) ecotopes [21]. According to CHER and KW herbarium collections, it is also known from Transcarpathia, Bukovinian Cis-Carpathian, Prut-Dnister interfluve, Zhytomyr Polissia and Roztochchya [13].

In Bukovinian Cis-Carpathian, S. ciliatum was first recorded in 2007 [22]. Later some more new localities were found. Very likely, this species penetrated in the The Bukovinian Cis-Carpathian from Romania where it had been determined as potential invasive [24-25]. The status of the species in Poland the same [30].

The aim of the article is to study of current distribution of $S$. ciliatum in the Bukovinian Cis-Carpathian, rate and character of dispersal, to determine ecological and coenotic characteristics and estimate the possible consequences of its naturalization in the region.

\section{MATERIAL AND METHODS}

Investigations are based on the original data obtained during fieldwork over the years 2007-2016 and an examination of herbarium collections of the Yuryi Fedkovych Chernivtsi National University (CHER) and M.G. Kholodny Institute of Botany, NAS of Ukraine $(K W)$.

The schematic map of the $S$. ciliatum distribution in the The Bukovinian CisCarpathian was prepared by the grid method of plant mapping using Maplnfo Professional version 12.5 software packages, according to Atlas Florae European adapted for regional territories [3]. The phytosociological surveys were performed with using ecological and floristic criteria of plant community releves. The phytosociological releves were carried out by the method of transformation of phytocoenotic tables with using the program

ISSN 1996-4536 (print) • ISSN 2311-0783 (on-line) • Біологічні Студії / Studia Biologica • 2017 • Том 11/№2 • С. 103-114 
package FICEN 2 [28]. The calculation of score synphytoindication indices was performed with the use of JUICE 6.5 program [29].

Ecological analysis was made according to the phytoindicatory scales $[6,20]$. Syntaxonomic scheme of plant communities with the participation of S. ciliatum was compiled following by Vegetation of Europe [14-16].

\section{RESULTS}

The information on the distribution of $S$. ciliatum in the The Bukovinian CisCarpathian generalized on based of the herbarium collections CHER and $K W$ data and fieldwork is given in fig. 1 and list mentioned below.

List of localities of S. ciliatum in Chernivtsi Region:

1. Glyboka Distr., Glyboka-Bukovynska station, along railway tracks, 12.10. 2007, I. Chorney, V. Budzhak, A. Tokaryuk (CHER); the same, 12.10. 2007, V.V. Protopopova, M.V. Shevera $(K W)$.

2. Glyboka Distr., vicinity of Cherepkivtsi vill., Vadul-Seret railway station, along railway tracks, 12.10. 2007, I. Chorney, V. Budzhak, A. Tokaryuk (CHER); the same, 12.10. 2007, V.V. Protopopova, M.V. Shevera (KW).

3. Storozhynets Distr., Storozhynets, railway station, 20.09. 2009, A. Tokaryuk (CHER).

- Storozhynets Distr., Storozhynets, along railway, 18.10. 2009, A. Tokaryuk (CHER).

4. Storozhynets Distr., Storozhynets, along road, 21.11. 2009, A. Tokaryuk (CHER);

- Storozhynets Distr., Storozhynets, along field road, 03.11. 2013, A. Tokaryuk (CHER).

5. Storozhynets Distr., Storozhynets city, left bank of Siret River, 30.09. 2012, A. Tokaryuk (CHER).

S. ciliatum actively distributes in the The Bukovinian Cis-Carpathian in anthropogenic transformed plant communities. In an early stage of invasion and colonization of ruderalized plots with denuded soil by this species it is characterized by high density and number. In the overgrowing stage of the plots, when the total cover of grass increases and vegetation becomes closer, the mentioned population indices of the species decrease.

The species is an annual/terophyte. Due to some biological characteristics such as the short period of ontogenesis and high reproductively it can extend to rather a long distance from parent individuals mainly by virtue of disturbed plots with a significant proportion of denuded soil. However, a long keep of colonizing territory do not observed especially in case of the process of overgrowing.

The densest and numerous populations of S. ciliatum in the The Bukovinian CisCarpathian were revealed in Glyboka city in plant community related to artificial rubble plots between railway tracks within the Glyboka-Bukivynska railway station. Floristic composition of the community is rather poor and composed of 19 species. Its total projective cover comes to $30-40 \%$ and projective cover of S. ciliatum to 5-7\%. Diagnostic Eragrostis minor Host and Amaranthus albus L. dominated. Among the invasion species there are Conyza canadensis (L.) Cronq.), Echinochloa crusgalli (L.) P. Beauv., Galinsoga parviflora Cav. and Phalacroloma annuum (L.) Dumort. (Table 1, relevél 1). According to ecological and floristic classification, the plant community belongs to 
association Eragrostio-Amaranthetum albi Morariu 1943, alliance Eragrostion cilianensiminoris Tx. ex Oberd. 1954, order Eragrostietalia J. Tx. ex Poli 1966 and class Digitario sanguinalis-Eragrostietea minoris Mucina, Lososová et Šilc in Mucina et al. 2016.

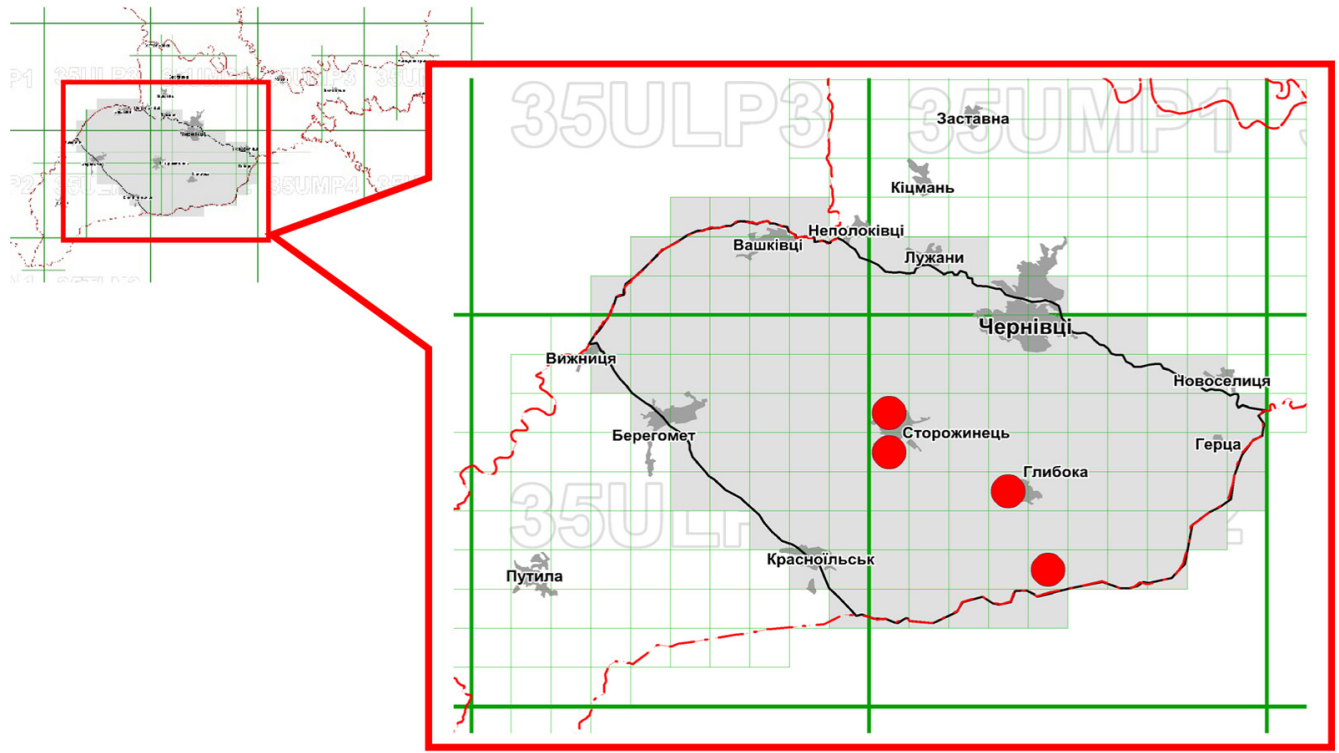

Map of localitets of Symphyotrichum ciliatum (Lindl.) Nesom in the Bukovinian Cis-Carpathian Карта поширення Symphyotrichum ciliatum (Lindl.) Nesom у Буковинському Передкарпатті

Table 1. Phytocoenotic characteristics of plant communities with participation of Symphyotrichum ciliatum (Lindl.) Nesom in the Bukovinian Cis-Carpathian

Таблиця 1. Фітоценотична характеристика рослинних угруповань за участю Symphyotrichum ciliatum (Lindl.) Nesom у Буковинському Передкарпатті

\begin{tabular}{|l|c|c|c|c|c|c|}
\hline \multicolumn{1}{|c}{ Number of relevés } & 1 & 2 & 3 & 4 & 5 & 6 \\
\hline Total projective cover, \% & $30-40$ & 70 & 50 & 70 & & 100 \\
\hline Total number of species & 19 & 24 & 24 & 20 & 30 & 26 \\
\hline Number of syntaxa & 1 & 2 & & 3 & 4 & 5 \\
\hline Symphyotrichum ciliatum & $\mathbf{2}$ & $\mathbf{1}$ & $\mathbf{+}$ & $\mathbf{+}$ & $\mathbf{2}$ & $\mathbf{+}$ \\
\hline
\end{tabular}

D.s. Ass. Eragrostio-Amaranthetum albi

\section{Eragrostis minor}

Amaranthus albus

\section{D.s.}

Echinochloa crusgalli

Setaria glauca

Portulaca oleracea

\section{D.s. Ass. Lolio-Plantaginetum majoris}

Plantago major

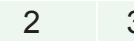

Lolium perenne

Lepidotheca suaveolens
2

1 
D.s. Ass. Polygonetum avicularis

Polygonum aviculare

$1 \quad 2 \quad 2$

Poa annua

D.s. Cl. Polygono-Poetea annua

Taraxacum officinale

Medicago lupulina

Lepidium ruderale

Potentilla anserina

D.s. Ass. Odontito-Ambrosietum artemisiifoliae

Ambrosia artemisiifolia

$\begin{array}{llllll}5 & 2 & 2 & 3 & 1\end{array}$

Odontites vulgaris

D.s. Ass. Convolvulo-Agropyretum repentis

Calamagrostis epigeios

Elytrigia repens

$\cdot \cdot \cdot \cdot \cdot 1$

Phalacroloma annuum

D.s. Cl. Artemisietea vulgaris

Artemisia vulgaris

Erigeron canadensis

Daucus carota

Cirsium arvense

Arctium lappa

Cichorium intybus

Arctium tomentosum

Lactuca serriola

Linaria vulgaris

Melilotus officinalis

\section{D.s. Cl. Sisymbrietea}

Amaranthus retroflexus

Galinsoga urticifolia

Matricaria perforata

Atriplex patula

Chenopodium album

Galinsoga parviflora

Ranunculus sardous

Xanthoxalis dillenii

\section{D.s. Cl. Epilobietea angustifolii}

\section{Galega officinalis}

Glechoma hederacea

Urtica dioica

Ranunculus repens

Rumex confertus

ISSN 1996-4536 (print) • ISSN 2311-0783 (on-line) • Біологічні Студії / Studia Biologica • 2017 • Том 11/№2 • С. 103-114 


\begin{tabular}{|c|c|c|c|c|c|c|}
\hline \multicolumn{7}{|c|}{ D.s. Cl. Molinio-Arrhenatheretea } \\
\hline Plantago lanceolata & . & . & 1 & 1 & 1 & + \\
\hline Trifolium repens & . & 1 & 1 & . & + & . \\
\hline Trifolium pratense & . & . & + & . & + & + \\
\hline Poa pratensis & . & . & + & 1 & . & 1 \\
\hline Agrostis tenuis & . & . & . & . & 1 & 1 \\
\hline Festuca pratensis & . & . & . & . & . & + \\
\hline Phleum pratense & . & . & . & . & . & 1 \\
\hline Dactylis glomerata & . & . & . & . & . & 2 \\
\hline Cerastium holosteoides & + & . & . & . & . & . \\
\hline Trifolium hybridum & . & . & . & + & . & . \\
\hline Mentha arvensis & . & . & . & + & . & . \\
\hline \multicolumn{7}{|l|}{ Other species: } \\
\hline Achillea submillefolium & + & . & + & . & + & + \\
\hline Lotus ucrainicus & . & . & + & . & + & 1 \\
\hline Polygonum persicaria & . & + & . & . & . & + \\
\hline Bidens tripartita & 1 & . & + & . & . & . \\
\hline Barkhausia setosa & . & . & + & . & + & . \\
\hline Chaenorhinum minus & . & . & + & . & + & . \\
\hline Potentilla reptans & . & . & . & . & + & + \\
\hline
\end{tabular}

The species occurred only in one relevé: Anchusa officinalis (5 [+]); Anisantha tectorum (2 [1]); Berteroa incana (5 [+]); Echium vulgare (5 [+]); Eragrostis pilosa (4 [1]); Galium verum (5 [+]); Geum urbanum (6 [+]); Inula britannica (2 [+]); Juncus bufonius (2 [1]); Juncus tenuis (6 [+]); Lepidium densiflorum (5 [+]); Oenothera biennis $(5[+])$; Poa compressa $(3[+]) ;$ Polygonum convolvulus (1 [+]); Potentilla supina $(4[+])$; Swida sanquinea (5 [+]); Xanthium albinum (5 [1])

Види, які трапляються в одному описі: Anchusa officinalis (5 [+]); Anisantha tectorum (2 [1]); Berteroa incana (5 [+]); Echium vulgare (5 [+]); Eragrostis pilosa (4 [1]); Galium verum $(5[+])$; Geum urbanum (6 [+]); Inula britannica (2 [+]); Juncus bufonius (2 [1]); Juncus tenuis (6 [+]); Lepidium densiflorum (5 [+]); Oenothera biennis (5 [+]); Poa compressa (3 [+]); Polygonum convolvulus (1 [+]); Potentilla supina $(4[+]) ;$ Swida sanquinea $(5[+])$; Xanthium albinum (5 [1])

Association localities of the relevés:

1. Glyboka, railway station, along railway, 12.10. 2007, A. Tokaryuk;

2. Glyboka, railway station, along railway, 29.07. 2008, A. Tokaryuk;

3. Storozhynets, railway station, 21.09. 2009, A. Tokaryuk;

4. Storozhynets, railway station, 21.09.2 009, A. Tokaryuk;

5. Glybotskyi Distr., Cherepkivtsi vill., Vadul-Siret railway station, 12.10. 2007, A. Tokaryuk;

6. Glyboka, railway station, $12.10 .2007 ; 29.07 .2008$, A. Tokaryuk

Описи виконано:

1. смт Глибока, залізничний вокзал, уздовж залізничної колії, 12.10. 2007, А. Токарюк;

2. смт Глибока, залізничний вокзал, уздовж залізничної колії, 29.07. 2008, А. Токарюк;

3. м. Сторожинець, залізничний вокзал, 21.09. 2009, А. Токарюк;

4. м. Сторожинець, залізничний вокзал, 21.09.2 009, А. Токарюк;

5. Глибоцький р-н, с. Черепківці, залізнична станція Вадул-Сірет, 12.10. 2007, А. Токарюк;

6. смт Глибока, залізничний вокзал, 12.10. 2007, 29.07. 2008, А.Токарюк

Number of syntaxa: 1 - Eragrostio-Amaranthetum albi; 2 - Lolio-Plantaginetum majoris; 3 Polygonetum arenastri; 4 - Odontito-Ambrosietum artemisiifoliae; 5 - Convolvulo-Agropyretum repentis

Номери синтаксонів: 1 - Eragrostio-Amaranthetum albi; 2 - Lolio-Plantaginetum majoris; 3 Polygonetum arenastri; 4 - Odontito-Ambrosietum artemisiifoliae; 5 - Convolvulo-Agropyretum repentis

ISSN 1996-4536 (print) • ISSN 2311-0783 (on-line) • Біологічні Студії / Studia Biologica • 2017 • Том 11/№2 • С. 103-114 
The plant community of association Lolio-Plantaginetum majoris (Linkola 1921) Beger with participation of $S$. ciliatum was found along a path at a beet collection in the territory Glyboka-Bukovynska station. Its total projective cover comes to $80 \%$ and projective cover of $S$. ciliatum is $1-2 \%$. Floristic composition of association composed of 24 species. The diagnostic Lolium perenne L., Plantago major L. and Lepidotheca suaveolens (Pursh) Nuttm dominate. Components of the plant community are invasive Ambrosia artemisiifolia L. (50-60 \%), Galinsoga urticifolia (Kunth) Benth. and Phalacroloma annuum (Table 1, relevé 2).

The association belongs to alliance Polygono-Coronopodion Sissingh 1969 order Polygono arenastri-Poetalia annuae Tx. in Géhu et al. 1972 corr. Rivas-Mart. et al. 1991, class Polygono-Poetea annuae Rivas-Mart. 1975 [26].

Within alliance Polygono-Coronopodion S. ciliatum have been found in plant community of association Polygonetum arenastri Gams 1927 confined to a roadside on the territory of Storozhynets railway station. The number of species in the coenosis varies from 20 to 25 . Its total projective cover is $50-70 \%$. Diagnostic species of association Plantago major L. (20-50 \%), Poa annua L. (2-3\%), and Polygonum aviculare L. (5-7 \%) dominate. S. ciliatum occurs rare. Among invasive species Ambrosia artemisiifolia (5-7 \%), Conyza canadensis, Echinochloa crusgalli (2-3 \%), Galinsoga urticifolia, Phalacroloma annuum, Setaria glauca (L.) P. Beauv. (2-3\%), and Xanthoxalis dillenii (Jacq.) Holub are observed (Tabl. 1, relevés 3-4).

Plant community of association Odontito-Ambrosietum artemisiifoliae Mucina 1993 with participation of $S$. ciliatum was revealed in Vadul-Siret railway station near Cherepkivtsi village of Glyboka District related to open places along path between railway tracks. Total projective cover is $80 \%$, projective cover of $S$. ciliatum is $1-2 \%$. Diagnostic species: Ambrosia artemisifolia is dominant and Odontites vulgaris Moench is co-dominant in the plant community. The plant community composes of 30 species of vascular plants, including invasive Cichorium intybus L., Conyza canadensis, Phalacroloma annuum, Setaria glauca and Xanthium albinum (Widder) H.Scholz (Table 1, relevél 5). It belongs to alliance Onopordion acanthii Br.-BI. 1926, order Onopordetalia acanthii Br.-BI. et Tx. ex Klika et Hadač 1944, class Artemisietea vulgaris Lohmeyer et al. ex von Rochow 1951 [11].

The isolated individuals of $S$. ciliatum occurs also in plant community of association Convolvulo-Agropyretum repentis Felföldy 1943 distributed along ground roads within the Glyboko-Bukovynska railway station territory. In this plant community (total projective cover $100 \%$ ) Elytrigia repens dominates with neglegiable dirt of Agrostis capillaris L., Calamagrostis epigeios (L.) Roth, Dactylis glomerata L., Festuca pratensis Huds., Phleum pratense L., and Poa pratensis L. Components of the association are invasive Ambrosia artemisiifolia, Cichorium intybus, Phalacroloma annuum and Juncus tenuis Willd. (Table 1, relevé 6). Plant community of association belongs to alliance Convolvulo arvensisAgropyrion repentis Görs 1967, order Agropyretalia intermedio-repentis T. Müller et Görs 1969, class Artemisietea vulgaris Lohmeyer et al. in Tx. ex von Rochow 1951.

Thus, on the basis of phytosociological relevél it was established that $S$. ciliatum in the Bukovinian Cis-Carpathian grows in five association, four order and three classes of synanthropic vegetation. The syntaxonomic scheme of plant community with participation of $S$. ciliatum in the region is given.

ISSN 1996-4536 (print) • ISSN 2311-0783 (on-line) • Біологічні Студії / Studia Biologica • 2017 • Том 11/№2 • C. 103-114 
Syntaxonomic scheme of plant community with participation of Symphyotrichum ciliatum (Lindl.) Nesom in Bukovinian Cis-Carpathian

Синтаксономічна схема рослинних угруповань за участю Symphyotrichum ciliatum (Lindl.) Nesom у Буковинському Передкарпатті

\section{Cl. Digitario sanguinalis-Eragrostietea minoris Mucina, Lososová et Šilc in Mucina et al. 2016}

Ord. Eragrostietalia J. Tx. ex Poli 1966

All. Eragrostion cilianensi-minoris Tx. ex Oberd. 1954

Ass. Eragrostio-Amaranthetum albi Morariu 1943

Cl. Polygono-Poetea annuae Rivas-Mart. 1975

Ord. Polygono arenastri-Poetalia annuae Tx. in Géhu et al. 1972 corr. Rivas-Mart. et al. 1991

All. Polygono-Coronopodion Sissingh 1969

Ass. Lolio-Plantaginetum majoris (Linkola 1921) Beger

Ass. Polygonetum arenastri Gams 1927

Cl. Artemisietea vulgaris Lohmeyer et al. in Tx. ex von Rochow 1951

Ord. Meliloto-Artemisitalia absinthii Elias 1979

All. Dauco-Melilotion albi Gors em Elias 1980

Ass. Odontito-Ambrosietum artemisiifoliae Mucina 1993

Ord. Agropyretalia intermedio-repentis T. Müller et Görs 1969

All. Convolvulo arvensis-Agropyrion repentis Görs 1967

Ass. Convolvulo-Agropyretum repentis Felföldy 1943

According to the main climatic indices, such as thermoregulation, ombrorezhime and criorezhime, S. ciliatum is characterized by stenotopic amplitude and belongs to submezoterms, subaridophytes and hemicriophytes (Table 2).

Table 2. Ecological characteristic (climatop) of Symphyotrichum ciliatum (Lindl.) Nesom in the Bukovinian Cis-Carpathian

Таблиця 2. Екологічна характеристика (кліматоп) Symphyotrichum ciliatum (Lindl.) Nesom у Буковинському Передкарпатті

Indices of climatic factors (points), ecological groups, width of ecological amplitude

$\mathrm{Tm}^{*}$

$\underline{8.78-9.90}$

9.26

Stenotopic submezoterm
Om

$11.07-11.65$

11.38

Stenotopic subarridophyte
$\mathrm{Kn}$

$\underline{8.45-9.11}$

8.79

Stenotopic hemicontinental
$\mathrm{Cr}$

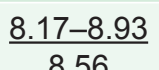

8.56

Stenotopic hemicriophyte

Comment: $\mathrm{Tm}$ - termorezhime, Om - ombrorezhime, $\mathrm{Kn}$ - continental climate, $\mathrm{Cr}$ - criorezhime; its and in the table 3 indicated: in numerator - value of tolerance amplitude, in denominator - mean value of tolerance amplitude to ecological factor

Примітка: $\quad \mathrm{Tm}$ - терморежим, Om - омброрежим, Kn - континентальність клімату, $\mathrm{Cr}$ - кріорежим; тут і в табл. 3 - у чисельнику вказується величина амплітуди толерантності, у знаменнику середнє значення амплітуди толерантності до цього екологічного фрактора

In the region the in relation to the water regime of the soil and the variability of moisture $S$. ciliatum is stenotypic mesophyte and hemihydroconstrastophile and grows

ISSN 1996-4536 (print) • ISSN 2311-0783 (on-line) • Біологічні Студії / Studia Biologica • 2017 • Том 11/№2 • С. 103-114 
in forest-meadow ecotopes with complete blotting root zone and melted water (Wnp = $100-145 \mathrm{~mm}$ ) (Table 3). It grows on slightly acidic $(\mathrm{pH}=5.5-6.5)$, enriched with salts, relatively nitrogen poor soils of mineral nitrogen and avoids carbonate substrates.

Table 3. Ecological characteristic (edaphotop) of Symphyotrichum ciliatum (Lindl.) Nesom in the Bukovinian Cis-Carpathian

Таблиця 3. Екологічна характеристика (едафотоп) Symphyotrichum ciliatum (Lindl.) Nesom у Буковинському Передкарпатті

\begin{tabular}{|c|c|c|c|c|c|c|}
\hline \multicolumn{7}{|c|}{$\begin{array}{l}\text { Indices of edaphic factors (pointsy), ecological groups, } \\
\text { wide of ecological amplitude }\end{array}$} \\
\hline $\mathrm{Hd}^{*}$ & $\mathrm{fH}$ & Rc & $\operatorname{Tr}(\mathrm{SI})$ & $\mathrm{Ca}$ & $\mathrm{Nt}$ & $\mathrm{Ae}$ \\
\hline $10.73-11.60$ & $\underline{7.04-7.75}$ & $\underline{7.79-8.05}$ & $\underline{7.78-8.32}$ & $\underline{6.22-7.13}$ & $\underline{5.88-6.82}$ & $\underline{6.25-7.16}$ \\
\hline 11.27 & 7.38 & 7.94 & 8.15 & 6.82 & 6.45 & 6.84 \\
\hline $\begin{array}{l}\frac{0}{2} \\
\frac{1}{0} \\
\frac{0}{0} \\
\mathbb{0} \\
\frac{0}{5} \\
\frac{0}{0} \\
0 \\
0 \\
\frac{0}{0} \\
\frac{0}{\omega}\end{array}$ & 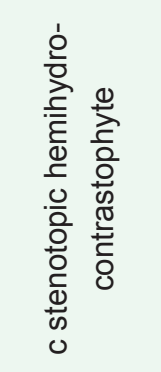 & $\begin{array}{l}\frac{0}{0} \\
\frac{1}{0} \\
\frac{0}{0} \\
\frac{0}{0} \\
\frac{0}{0} \\
\frac{0}{5} \\
\text { क } \\
\frac{0}{0} \\
\frac{0}{0} \\
\frac{0}{0} \\
\frac{0}{\omega}\end{array}$ & 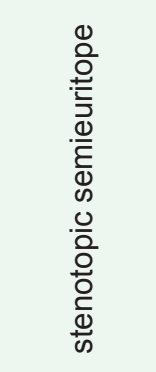 & 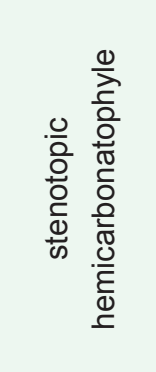 & 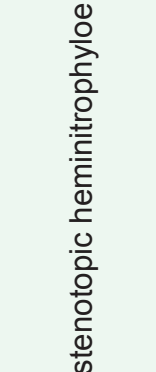 & 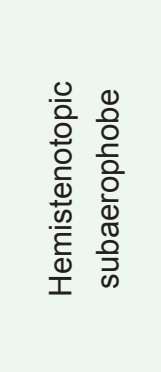 \\
\hline
\end{tabular}

Comment: $\mathrm{Hd}$ - humidity of soil, $\mathrm{fH}$ - moisture change, $\mathrm{Rc}$ - soil acidity, $\mathrm{SI}$ - soil salinity, $\mathrm{Ca}$ - content of carbonates in soil, $\mathrm{Nt}$ - content of nitrogen in soil, $\mathrm{Ae}$ - soil aeration

Примітка: $\mathrm{Hd}$ - вологість ґрунту, fH - змінність зволоження, Rc - кислотність ґрунту, $\mathrm{SI}$ - засоленість ґрунту, Сa - вміст у ґрунті карбонатів, $\mathrm{Nt}$ - вміст азоту у ґрунті, Ae - аерація ґрунту

As to rate and character of distribution in the Bukowinian Cis-Carpathian S. ciliatum is potential invasive species.

According to the classification of habitats on the territory of Ukrainian Carpathians and Transcarpathian Lowlands [4], plant communities with S. ciliatum are comprised of the next habitats: "Sand-clay deposits (shifts) of quarries and anthropogenic substrates of a moving type"; "Seliteb area"; "Areas with ruderal xeromesophyte vegetation (beyond the seliteb area)"; "Muddy river banks with Chenopodion rubri p. p. and Bidention p. p. Vegetation". Last one is under threat of disappearance and need the protection on European level because of its presence in the Natura 2000, in particular, 3270 "Muddy river banks with Chenopodion rubri p. p. and Bidention p. p. Vegetation" [19].

\section{CONCLUSION}

The S. ciliatum in the Bukovinian Cis-carpathian occurs in five associations, four unions, four orders, and three classes of synanthropic vegetation: Ass. EragrostioAmaranthetum albi Cl. Digitario sanguinalis-Eragrostietea minoris, Ass. LolioPlantaginetum majoris and Polygonetum arenastri Cl. Polygono-Poetea annuae, Ass. Odontito-Ambrosietum artemisiifoliae and Convolvulo-Agropyretum repentis $\mathrm{Cl}$. Artemisietea vulgaris. 
The species in the region has stenotope ecological amplitude and according to main climatic and edaphic indices is submezoterm, subaridophyte, hemicontinental, hemicriophyte, mesophyte, hemihydroconstrastophile, subacidophile, semievitrophe, gemicarbonatophyte, heminitrophylous and subaeroophobe. One can consider this species as potential invasive.

\section{ACKNOWLEDGEMENT}

The authors would like to thank the Dr. Olena V. Borysova (M.G. Kholodny Institute of Botany, NAS of Ukraine) for valuable comments and editing of English text.

1. Anastasiu P., Negrean G., Samoilă C., Memedemin D., Cogălniceanu D. A comparative analysis of alien plants species along the Romanian Black Sea coastal area. The role of harbours.

J. Coast. Conserv, 2011; 15: 595-606.

2. Broż E., Podgórska M. Symphyotrichum ciliatum (Brachyactis ciliata) (Asteraceae) in Poland. Fragm. Flor. et Geobot. Polon, 2005; 12(2): 291-299.

3. Budzhak V. V., Chorney I. I., Tokaryuk A. I. Supplement to the method of flora species mapping (Chernivtsy district example). Scientific Herald of Chernivtsi University: collection of scientific papers. Biology, 2009; 455: 168-170. (In Ukrainian).

4. Catalogue of type habitats of Ukrainian Carpathian and Transcarpathian lowland / Ed. B. Prots and O. Kagalo. Lviv: Merkator Press, 2012. 294 p. (In Ukrainian).

5. COSEWIC assessment and update status report on the Gulf of St. Lawrence aster Symphyotrichum laurentianum in Canada. Committee on the Status of Endangered Wildlife in Canada. Ottawa, 2004: 39.

6. Didukh Ya.P. Prepararation of edition of "Ecoflora of Ukraine" [as base of phytoindication state of ecosystem]. Ukr. Phytocoen J, 1998; 1(10): 4-17. (In Ukraininian).

7. Dubyna D.V., Protopopova V.V., Dubovik O.M. New for the flora of Ukr. SSR species Brachyactis Ledeb. Ukr. Bot. J, 1986. 43(2): 51-54. (In Ukrainian).

8. Geydeman T.S. Determinator of Higher plants of Moldavian SSR. Kishinyov: Shtinca Press, 1986: 530. (In Russian).

9. Guzik J. Hal.da Huty im. Sendzimira w Krakowie - miejsciem występowania interesujących obcych gatunków roślin. Sesja Naukowa: Hal-da poprzemyslowa - obiekt obserwacji procesow biologicznych. Uniwersytet Śląski w Katowicach, 2002: 7.

10. Guzik J. Hal.da Huty im. Sendzimira w Krakowie - miejscem występowania interesujących obcych gatunków roślin. Arch. Ochr. Środ, 2003; 29(2): 13-19.

11. Jarolímek I., Zaliberová M., Mucina L., Mochnacký S. Rastlinné spoločenstvá Slovenska 2. Synantropná vegetácia. Bratislava: Veda Vydavatel'stvo Slovenskej Akadémie Vied, 1997: $416 \mathrm{~s}$.

12. Krylov P.F. Flora of Western Siberia. Vol. 11. Tomsk: Botanical Section of Tomsk Nature Society, 1949. P. 2630-3070. (In Russian).

13. Kuzyarin A..T. New for Lviv Region alien species. Sc. Letterrs of State Natural History Museum, 2012; 28: 143-144. (In Ukrainian).

14. Matuszkiewicz W. Przewodnik do oznaczania zbiorowisk roślinnych Polski. Warszawa: Wydawnictwo naukowe PWN, 2001. 537 s.

15. Moravec J. a kol. Roslinna společenstva České republiky a jejich ochrozeni. 2 vydání. ČR: Okresni vlastivědné muzeum, 1995. 206 s.

16. Mucina L., Bültmann H., Dierßen K., Theurillat J.-P., Raus T., Čarni A., Šumberová K., Willner W., Dengler, J., Gavilán García R., Chytrý M., Hájek M., Di Pietro R., lakushenko D., Pallas J., Daniëls F.J.A., Bergmeier E., Santos Guerra A., Ermakov N., Valachovič M., Schaminée J.H.J., Lysenko T., Didukh Ya.P., Pignatti S., Rodwell J.S., Capelo J., Weber H.E.,

ISSN 1996-4536 (print) • ISSN 2311-0783 (on-line) • Біологічні Студії / Studia Biologica • 2017 • Том 11/№2 • С. 103-114 
Solomeshch A., Dimopoulos P., Aguiar C., Hennekens S.M. \& Tichý, L. Vegetation of Europe: Hierarchical floristic classification system of vascular plant, bryophyte, lichen, and algal communities. Applied Vegetation Science, 2016; 19(1): 3-264.

17. Nesom G.L. Review of the taxonomy od the Aster sensu lato (Asteraceae: Astereae), emphasizing the New World species. Phytologica, 1994; 77(3): 141-297.

18. Nobis M., Pliszko A. New localities of Symphyotrichum ciliatum (Asteraceae) in Poland. Acta Mus. Siles. Sci. Natur, 2016; 65: 283-286.

19. Habitat conception of conservation of biodiversity: bases documents of EU / ed. O.O. Kagalo \& B.H. Prots. Lviv ZUKTs press, 2012. 278 p. (In Ukrainian).

20. Plyuta P.G. Principel of formation and used of phytoindication climatic scales. Ukr. Phytocoe, J, 1998; C; 1(10): 17-27. (In Ukrainian).

21. Protopopova V.V., Shevera M.V., Mosyakin S.L., Solomakha V.A., Solomakha T.D., Vasylyeva T.V., Petryk S.P. Invasive species in flora of Northern Cis Blacj Sea area. Kyiv: Phytosociocentre Press, 2009. 56 p. (In Ukrainian).

22. Protopopova V.V., Shevera M.V., Chorney I.I., Tokaryuk V.V., Korzhan K.V. The transformer species in flora of Bukovinian Cis-Carpathian. Ukr. Bot. J, 2010; 67(6): 852-864. (In Ukrainian).

23. Sîrbu C., Ferus P., Eliáš P. jun., Samuil C., Oprea A. Symphyotrichum ciliatum in Romania: trends of spread and invaded plant communities. Open Life Sciences, 2015; 10: 147-164.

24. Sîrbu C., Oprea A. Plante adventive în flora Romániei. Iaşi: Editura "Ion lonescu de la Brad", 2011: 413-414.

25. Sîrbu C., Oprea A., Eliáš $P$. jun., Ferus $P$. New contribution to the study of alien flora in Romania. J. Plant Develop, 2011; 18: 121-134.

26. Shyshkin B.K. Genus Brachyactis Ledeb. In Flora of USSR. Vol. 25 / Ed. B.K. Shyshkin. Moscow; Leningrad: Institute of Botany, Acad. Sc. USSR, press, 1959: 631 p. (In Russian).

27. Solomakha V.A. Syntaxonomy of vegetation of Ukraine. Third approximation. Kyiv: Phytosociocentre Press, 2008. 296 p. (In Ukrainian).

28. Syrenko I.P. Creation a Databases for Floristic and Phytocoenologic Researches. Ukr. Fitotsen. Zb, 1996; A (1): 9-11.

29. Tichy L. JUICE, software for vegetation classification. J. Veg. Sci, 2002; 13: 451-453.

30. Tokarska-Guzik B., Dajdok Z., Zając M., Zając A., Urbisz A., Danielewicz W., Hołdyński C. Rośliny obcego pochodzenia w Polsce ze szczególnym uwzględnieniem gatunków inwazyjnych. Warszawa, 2012. 198 p.

31. Tucharz M., Nobis A., Nobis M. Chromosome data - a useful tool in taxonomy of Symphyotrichum ciliatum. Acta Biol. Cracov, 2011; Botan; 53(1): 117-119.

32. Tzvelev N.N. Genus Brachyactis Ledeb. In: Flora of European Part of USSR. Vol. 7 / ed. by N.N. Tzvelev. Sankt-Petersburg: Nauka Press, 1994. 195 p. (In Russian).

\section{ХОРОЛОГІЧНІ ТА ЕКОЛОГО-ЦЕНОТИЧНІ ОСОБЛИВОСТІ SYMPHYOTRICHUM CILIATUM (LINDL.) NESOM (ASTERACEAE) У БУКОВИНСЬКОМУ ПЕРЕДКАРПАТТІ}

\section{А. І. Токарюк', І. І. Чорней' , В. В. Буджак', В. В. Протопопова², М. В. Шевера}

1 Чернівецький національний університет імені Юрія Федьковича вул. Федьковича, 11, Чернівиі 58022, Україна e-mail: iichorney@ukr.net,vbudzhak@gmail.com

2 Закарпатський угорський інститут імені Ференца Ракоці II пл. Кошута, 6, Берегове, Закарпатська обл. 90200, Україна e-mail: protopopova.vira@gmail.com

${ }^{3}$ Інститут ботаніки ім. М.Г. Холодного НАН України вул. Терещенківська, 2, Київ 01004, Україна e-mail: shevera.myroslav@gmail.com 
Представлено результати вивчення поширення та еколого-ценотичної приуроченості адвентивного виду Symphyotrichum ciliatum (Lindl.) Nesom (Asteraceae) у Буковинському Передкарпатті (Україна). Виявлено нові локалітети виду в регіоні, в т.ч. у складі оселищ Natura 2000.

Уперше з'ясовано бальні показники провідних едафрічно-кліматичних фракторів виду. Встановлено, що вид вирізняється здебільшого стенотопною екологічною амплітудою. Відмічений у складі угруповань асоціації Eragrostio-Amaranthetum albi Morariu 1943 класу Digitario sanguinalis-Eragrostietea minoris Mucina, Lososová et Šilc in Mucina et al. 2016, асоціацій Lolio-Plantaginetum majoris (Linkola 1921) Beger та Polygonetum arenastri Gams 1927 класу Polygono-Poetea annuae Rivas-Mart. 1975, асоціацій Odontito-Ambrosietum artemisiifoliae Mucina 1993 та ConvolvuloAgropyretum repentis Felföldy 1943 класу Artemisietea vulgaris Lohmeyer et al. in Tx. ex von Rochow 1951, які приурочені до мезофітних, гемігідроконтрастофрільних, субацидофільних, семіевтрофрних, гемікарбонатофообних, гемінітрофрільних умов.

Ключові слова: Symphyotrichum ciliatum, Asteraceae, поширення, екологоценотична приуроченість, Буковинське Передкарпаття, Україна 